\title{
Tingkat Depresi Mahasiswa Keperawatan di Tengah Wabah COVID-19
}

\author{
Agus Santoso ${ }^{1}$, Wandria Robi Ardi ${ }^{*}$, Rikhan Luhur Prasetya ${ }^{1}$, Meidiana Dwidiyanti ${ }^{1}$, \\ Diyan Yuli Wijayanti ${ }^{1}$, Muhammad Mu'in ${ }^{1}$, Sarah Ulliya ${ }^{1}$, Fitria Handayani ${ }^{1}$, Madya \\ Sulisno', Maftukhatun Ni’mah ${ }^{1}$, Nur Aas Aisah ${ }^{1}$
}

${ }^{1}$ Departemen Ilmu Keperawatan Fakultas Kedokteran, Universitas Diponegoro, Semarang, Indonesia wandriarobi28@gmail.com

\begin{abstract}
Introduction: The emergence of the COVID-19 pandemic affected the mental health of students. Students feel stressed and sad, anxious, frustrated, confused and do not know how to overcome their conditions. Depression occurs because of negative thinking about oneself and others, so special management is needed in the midst of a COVID-19 pandemic. The aim of this study was to provide an overview of the depression levels of students in the pandemic.

Methods: The method in this study was a quantitative research with cross sectional approach. Descriptive analysis is used to provide a description of the level of depression that occurs in students. Data collection used the Beck Deperession Inventory II (BDI II), sampling used a total sample of 148 respondents (students with an average age of 18-20 years old). The process of collecting data is done by using the google form survey method.

Results: Students experienced mild mood disorders (25.7\%), severe depression (12.2\%), low depression $(8.1 \%)$, moderate depression $(0,7 \%)$ and extreme $(0.7 \%)$.

Conclusion: Depression in the pandemic of COVID-19 requires special attention in management to prevent mental disorders.
\end{abstract}

Keywords: Depression Level, Pandemic COVID-19, University Students.

\begin{abstract}
Abstrak
Pendahuluan: Munculnya pandemi COVID-19 memengaruhi kesehatan mental mahasiswa. Mahasiswa merasa stres dan sedih, cemas, frustasi, bingung dan tidak tahu cara untuk mengatasi kondisinya. Depresi terjadi karena berpikir negatif pada diri sendiri dan orang lain, sehingga perlu pengelolaan yang khusus di tengah pandemi COVID-19. Tujuan penelitian ini untuk memberikan gambaran tingkat depresi mahasiswa di tengah COVID-19.

Metode: Metode dalam penelitian ini adalah metode penelitian kuantitatif dengan pendekatan cross sectional. Analisis deskriptif digunakan untuk memberikan gambaran tingkat depresi yang terjadi pada 148 mahasiswa usia 18-20 tahun. Pengumpulan data menggunakan instrumen BDI II (Beck Deperession Inventory) II), pengambilan sampel menggunakan total sampel berjumlah 148 sampel. Proses pengumpulan data dilakukan dengan metode survey menggunakan google form.

Hasil: Mahasiswa mengalami gangguan mood ringan (25,7\%), depresi berat $(12,2 \%)$, depresi rendah $(8,1 \%)$, depresi sedang $(0,7 \%)$, dan ekstrem $(0,7 \%)$.

Kesimpulan: Gambaran depresi di tengah COVID-19 memerlukan perhatian khusus dalam pengelolaan untuk mencegah gangguan jiwa.
\end{abstract}

Kata kunci : Mahasiswa, Pandemi COVID-19, Tingkat Depresi. 


\section{PENDAHULUAN}

World Health Organization (WHO) telah menetapkan COVID-19 sebagai pandemik. Hal ini membuat pemerintah dan masyarakat dunia semakin waspada dengan penyebaran virus corona (Bouey \& Dong, 2020). Munculnya pandemi COVID-19 tidak hanya memengaruhi kesehatan fisik, namun juga memengaruhi kesehatan mental individu di seluruh dunia (Giacalone, Rocco, \& Ruberti, 2020).

Kebijakan-kebijakan besar telah diambil oleh negara-negara terjangkit sebagai upaya menghentikan penularan infeksi, salah satunya di Indonesia. Indonesia telah memberikan himbauan kepada masyarakatnya untuk melakukan social distancing dan physical distancing sesuai protokol WHO dengan memberlakukan Pembatasan Sosial Berskala Besar atau PSBB (Bouey \& Dong, 2020). Tak terkecuali di bidang pendidikan, sejak minggu ketiga bulan Maret 2020, Kementerian Pendidikan dan Kebudayaan Republik Indonesia (Kemendikbud RI) telah memberlakukan segala kegiatan pendidikan dilakukan secara daring termasuk di tingkat perguruan tinggi sebagai upaya mengurangi perkumpulan masal dan mencegah penularan COVID-19.

Perkuliahan daring atau perkuliahan tanpa tatap muka bukanlah solusi yang tanpa menimbulkan konsekuensi baru. Studi pendahuluan yang dilakukan seminggu setelah diberlakukannya perkuliahan daring pada 47 mahasiswa keperawatan menyebutkan bahwa mahasiswa merasa perkuliahan daring tidak efektif dan memiliki banyak kendala. Sebagian mahasiswa merasa stres dan sedih karena jaringan yang tidak stabil sehingga tidak dapat mengikuti perkuliahan dengan optimal, sebagian mahasiswa cemas karena tidak mampu membeli kuota internet, merasa tertekan karena banyaknya tugas yang diberikan oleh dosen dalam waktu yang singkat, dan sebagian besar mahasiswa semester akhir merasa frustasi tidak bisa lulus tepat waktu karena proses penelitian maupun bimbingan yang terhambat. Sebagian besar mahasiswa merasa bingung dan tidak tahu mengatasi kondisinya. Jika hal ini terusmenerus terjadi akan memengaruhi kondisi mental mahasiswa yang berdampak pada penurunan minat belajar, penurunan prestasi, penurunan kualitas lulusan bahkan dapat terjadi gangguan kesehatan mental pada mahasiswa (Giacalone et al., 2020). Gangguan mental yang mungkin terjadi di tengah kondisi pandemi diantaranya adalah depresi pada mahasiswa (Watnaya, Muiz, Sumarni, Mansyur, \& Zaqiah, 2020).

Sebuah survei yang dilakukan di Tiongkok pada awal wabah COVID-19 menemukan bahwa $53,8 \%$ responden mengalami dampak psikologisnya sedang hingga parah; $16,5 \%$ mengalami gejala depresi sedang hingga berat; 28,8\% mengalami gejala kecemasan sedang hingga berat, dan $8,1 \%$ mengalami tingkat stres sedang hingga berat (Wang et al., 2020). Penelitian yang dilakukan di China pada siswa selama pandemi covid-19 ditemukan bahwa sekitar $25 \%$ dari responden mengalami gejala kecemasan, yang positif berkorelasi dengan meningkatnya kekhawatiran tentang keterlambatan akademik, dampak ekonomi akibat pandemi, dan dampak pada kehidupan sehari-hari (Cao et al., 2020). Selanjutnya, di antara banyak survei siswa yang dikelola di seluruh dunia, satu survei oleh YoungMinds menunjukkan bahwa terdapat $83 \%$ responden muda setuju bahwa pandemi memperburuk kondisi kesehatan mental yang sudah ada sebelumnya, terutama karena penutupan sekolah, kehilangan rutinitas, dan koneksi sosial terbatas (Thomas, 2020). 
Belum ada angka yang pasti di Indonesia yang menyebutkan tentang tingkat depresi mahasiswa pada masa pandemi COVID-19. Sedangkan kasuskasus depresi pada mahasiswa semakin nyata. Apabila hal tersebut tidak ditangani dengan baik maka akan menimbulkan masalah yang lebih besar. Berdasarkan latar belakang di atas, peneliti tertarik untuk mengidentifikasi tingkat depresi mahasiswa keperawatan selama masa pandemi COVID-19.

\section{METODE}

Metode penelitian yang digunakan dalam penelitian ini adalah metode penelitian kuantitatif dengan pendekatan cross-sectional, suatu penelitian yang dilakukan dengan pengamatan sesaat. Penelitian dilakukan dalam suatu periode tertentu dan setiap objek studi hanya dilakukan satu kali pengamatan (Machfoedz, 2009). Pengumpulan data menggunakan instrument Beck Deperession Inventory II (BDI II). Pengambilan sampel menggunakan total sampel, dalam penelitian ini adalah mahasiswa program studi S1 keperawatan berusia 18-20 tahun yang berjumlah 148. Analisis deskriptif digunakan untuk memberikan gambaran tingkat depresi yang terjadi pada mahasiswa selama masa pandemi. Proses pengumpulan data dilakukan dengan metode survey menggunakan google form.

\section{HASIL}

Berikut merupakan hasil penelitian mengenai gambaran depresi mahasiswa. Distribusi Frekuensi Variabel Semester.

Tabel 1. Distribusi Frekuensi Variabel Semester $(n=148)$.

\begin{tabular}{lcc}
\hline Tingkat & Frekuensi & Persentase $(\%)$ \\
\hline Semester 1 & 1 & 0,7 \\
Semester 2 & 31 & 21,0 \\
Semester 4 & 70 & 47,3
\end{tabular}

\begin{tabular}{lcc}
\hline Tingkat & Frekuensi & Persentase (\%) \\
\hline Semester 5 & 1 & 0,7 \\
Semester 6 & 13 & 8,8 \\
Semester 8 & 32 & 21,6 \\
\hline Total & 148 & 100 \\
\hline
\end{tabular}

Tabel 2. Distribusi Frekuensi Tingkat Depresi $(n=148)$.

\begin{tabular}{lcc}
\hline Kategori & Frekuensi & Persentase (\%) \\
\hline Normal & 78 & 52,7 \\
Gangguan Mood & 38 & 25,7 \\
$\quad$ Ringan & & \\
Batas Depresi & 18 & 12,2 \\
Rendah & 12 & 8,1 \\
Sedang & 1 & 0,7 \\
Ekstrem & 1 & 0,7 \\
\hline Total & 148 & 100 \\
\hline
\end{tabular}

\section{PEMBAHASAN}

Mahasiswa berada pada masa transisi remaja akhir dan dewasa awal. Mahasiswa merupakan seseorang yang sedang menjalani serangkaian proses pendidikan di instansi terkait. Setiap periode usia manusia memiliki tugas perkembangan (Permana, Wardati, \& Sirodj, 2017). Tugas perkembangan mahasiswa dipengaruhi oleh beberapa faktor seperti motivasi, faktor keluarga, lingkungan kampus dan aktif organisasi. Faktor yang paling signifikan berpengaruh pada tugas perkembangan mahasiswa adalah dukungan dari keluarga (Hulukati \& Djibran, 2018).

Hopkins (2007 dalam Utami \& Murti (2017) menjelaskan bahwa setiap tahap perkembangan seseorang akan menghadapi sebuah krisis. Krisis ini bukanlah sebuah bencana, namun merupakan sebuah tugas yang harus diselesaikan, sehingga dapat meningkatkan kemampuan seseorang dalam menghadapi tugas perkembangan selanjutnya. Seseorang yang berhasil menyelesaikan krisis yang dihadapinya, maka tahap perkembangannya pun akan 
sehat. Pada masa dewasa awal yaitu pada usia 20-30an individu mengalami krisis keintiman versus isolasi. Pada tahap ini, individu menghadapi tugas perkembangan yang berkaitan dengan pembentukan relasi intim dengan orang lain. Erikson (1969 dalam Utami \& Murti, 2017) mendeskripsikan keintiman sebagai menemukan diri sendiri di satu sisi, namun kehilangan diri sendiri di sisi lain.

Kegagalan

perkembangan psikososial pada dewasa muda yaitu tahap keintiman dapat menimbulkan masalah baru seperti adanya masalah keuangan, sosial, keluarga, lapangan pekerjaan, maupun lingkungan dan aktivitas rutin di kampus. Apabila tugas perkembangan psikosisal pada dewasa muda tidak tercapai, dapat menyebabkan individu mengalami kesulitan dalam menjalin hubungan dekat dengan individu lain. Dampak lainnya, individu juga akan merasa tidak percaya diri sehingga akan menarik diri dari sosial (Fortinash, 2012 dalam Mutyah, Ayu, \& Damayanti, 2020). Hambatan tersebut perlu ditangani secara khusus untuk menghindari disorganisasi, emosi yang kacau dan stres (Permana et al., 2017).

Hasil penelitian menunjukkan bahwa terdapat $8,1 \%$ mahasiswa mengalami depresi ringan namun, masih terdapat mahasiswa yang berada pada tingkat depresi sedang dan depresi ekstrem. Mahasiswa lazim memiliki gangguan psikologis terkait kesulitan dan peraturan akademik dalam keadaan normal (American College Health Association, 2019).

Depresi pada mahasiswa sangat lazim terkait dengan masalah akademik, finansial, maupun tekanan interpersonal. Mahasiswa merupakan kelompok khusus yang bertahan pada periode transisi dari masa remaja hingga dewasa dan mungkin mengalami masa paling menegangkan dalam hidup. Menjalani transisi ini dapat menyebabkan peningkatan risiko depresi. Mencoba menyesuaikan diri, mempertahankan nilai yang baik, merencanakan masa depan, dan sering jauh dari rumah menyebabkan kecemasan bagi banyak mahasiswa. Sebagai reaksi terhadap stres ini, beberapa siswa mengalami depresi karena tidak dapat berdaptasi dengan respon menangis, melewati kelas, atau mengisolasi diri tanpa menyadari mengalami depresi. Penelitian menemukan bahwa siswa lajang rentan terhadap depresi, dibandingkan dengan siswa yang sudah menikah. Ini mungkin karena siswa lajang menghadapi peristiwa yang lebih menegangkan daripada siswa yang menikah, seperti pekerjaan, ekonomi, kelulusan, dan tekanan pernikahan (Sarokhani et al., 2013).

Berdasarkan hasil penelitian terdapat sebagian besar responden yang mengalami depresi normal saat karantina. Hasil ini sejalan dengan penelitian $\mathrm{Lu}$, Nie, \& Qian (2020) yang menunjukkan dampak yang berbeda selama karantina. Penelitian ini menunjukkan bahwa terdapat hubungan positif antara karantina dan sikap optimis terkait pemberitaan terkontrolnya penyebaran virus corona. Responden merasa aman saat melakukan karantina diri, sehingga terhindar dari penyebaran virus, menunjukkan tingkat depresi yang rendah dan peningkatan kebahagiaan.

Hasil data penelitian lainnya masih menunjukkan mahasiswa yang mengalami depresi gangguan mood ringan, depresi, depresi rendah, depresi sedang dan terdapat mahasiswa yang memiliki depresi ekstrem. Hal ini dapat dikaitkan dengan kondisi lingkungan yang sedang pandemi, sistem kuliah daring, dan keadaan lainnya memunculkan gangguan psikologis tersebut. 
Mahasiswa mengalami penurunan motivasi terhadap studi, peningkatan tekanan untuk belajar mandiri, pengabaian rutinitas sehari-hari, dan berpotensi putus sekolah pada kondisi pandemi COVID-19 (Grubic, Badovinac, \& Johri, 2020). Penelitian yang dilakukan di China pada siswa selama pandemi covid-19 ditemukan bahwa sekitar $25 \%$ dari responden mengalami gejala kecemasan, yang positif berkorelasi dengan meningkatnya kekhawatiran tentang keterlambatan akademik, dampak ekonomi akibat pandemi, dan dampak pada kehidupan sehari-hari (Cao et al., 2020). Selanjutnya, di antara banyak survei siswa dikelola di seluruh dunia, satu survei oleh YoungMinds. Terdapat $83 \%$ responden muda setuju bahwa pandemi memperburuk kondisi kesehatan mental yang sudah ada sebelumnya, terutama karena penutupan sekolah, kehilangan rutinitas, dan koneksi sosial terbatas (Thomas, 2020).

Mahasiswa menghadapi berbagai tantangan pada masa pandemi covid-19. Mahasiswa khawatir kondisi ini akan mempengaruhi kinerja saat menjalani ujian. Mahasiswa tingkat akhir harus menghentikan proyek penelitian dan magang ketika universitas mengevakuasi mahasiswa dari kampus. Arahan yang jelas harus diberikan terkait prosedur administrasi ujian jangka menengah, tugas, dan proyek (Sahu, 2020).

Pandemi COVID-19 memiliki dampak psikologis bagi mahasiswa. Masalah yang dimunculkan mencakup beragam aspek, seperti akademik, finansial, maupun kesehatan fisik. Mahasiswa akan mengalami gangguan pada program penelitian dan magang sehingga dapat menghambat penyelesaian tugas studi, kesulitan untuk membayar kamar sewa, atau biaya kembali ke rumah. Masalah ini dapat memicu stress yang mengakibatkan munculnya gangguan seperti penyalahgunaan zat, kesulitan tidur, kehilangan nafsu makan bahkan depresi (Hamada \& Fan, 2020).

Stress akan direspon oleh tubuh dengan mengeluarkan hormon kortisol dan adrenalin. Hormon ini akan meningkat saat seseorang stress. Tingginya hormon kortisol dan adrenalin akan menekan efektivitas sistem kekebalan tubuh. Penindasan sistem kekebalan membuat tubuh rentan terhadap penyakit dan infeksi. Hal ini penting disadari oleh mahasiswa untuk senantiasa menjaga kesehatan mental (Bhat et al., 2020).

Berdasarkan hasil penelitian menunjukkan bahwa responden berasal dari semua tingkatan dalam satu jurusan. Hal ini dapat menyebabkan dampak psikologis bagi mahasiswa tingkat pertama dimungkinkan karena kurangnya dukungan orangtua terkait jurusan yang dipilih, adanya masa transisi antara sekolah menengah atas menuju masa perkuliahan dan adaptasi dengan lingkungan sekitar, pergaulan maupun gaya hidup yang berubah. mahasiswa tingkat menengah memiliki tuntutan akademik yang mulai banyak dikarenakan organisasi intra maupun ekstra kampus yang menyita waktu dan energi selama periode kepengurusan. Mahasiswa tingkat akhir yang memiliki tuntutan untuk segera menyelesaikan tugas belajar, persiapan mencari pekerjaan, menyelesaikan tugas akhir, magang maupun hal-hal yang berkaitan dengan tugas semester akhir.

Mahasiswa yang memiliki gangguan psikologis tidak mampu mengikuti proses pembelajaran secara optimal. Beberapa masalah muncul berkaitan dengan sistem kuliah online, seperti kesiapan, penguasaan teknologi, sinyal, dan kendala lainnya. Penelitian lain, menunjukkan bahwa terdapat hubungan yang erat antara kuliah online dengan sikap mental mahasiswa. Terdapat $60,5 \%$ mahasiswa yang siap 
berdaptasi dengan kuliah daring meski kesulitan dalam menggunakan aplikasi pembelajaran terkait sebesar $32,5 \%$. Terdapat 59,5\% mahasiswa keberatan atas tugas yang diberikan dosen, sehingga sumber rujukannya hanya sebatas akses internet. Kondisi ini menyebabkan $60 \%$ mahasiswa mengalami sulit tidur karena dampak tugas ini. Sebagian besar hasil penelitian menunjukkan sebanyak 92\% mahasiswa memilih perkuliahan tatap muka di kelas dibanding perkuliahan daring (Watnaya, Muiz, Sumarni, Mansyur, \& Zaqiah, 2020).

Pembelajaran jarak jauh menjadi pilihan bagi universitas selama pandemi COVID-19. Mahasiswa melakukan kuliah, bimbingan dan pengumpulan tugas secara online. Hal ini berlaku pada mahasiswa tingkat akhir yang menjalani program magang, praktik klinik maupun penelitian. Dosen pembimbing secara aktif terlibat dalam membantu mahasiswa memaksimalkan pengalaman magang dan penelitian. Universitas dituntut untuk mengembangkan inovasi akademik sehingga siswa dapat memenuhi persyaratan kelulusan. Pusat karir universitas disarankan terus memfasilitasi pengembangan karier untuk mahasiswa (Cao et al., 2020).

Sistem pembelajaran daring memiliki beberapa kekurangan. Diperlukan kesiapan yang matang untuk mencapai sistem yang optimal. Penilaian daring yang dilakukan pada tugas yang dirancang untuk pembelajaran tatap muka adalah tugas yang menantang. Staf pengajar harus mengubah jenis penilaian agar sesuai dengan metode daring. Evaluasi akhir semester sulit dilakukan karena staff akademik tidak mengetahui apakah mahasiswa menjalani ujian dengan jujur. Pembelajaran maupun ujian melalui praktik juga sulit dilakukan dalam metode online (Sahu, 2020).
Mahasiswa harus beradaptasi dengan formula baru selama mengikuti proses akademik. Pembelajaran online didukung kuat oleh fasilitas internet. Hal ini akan menjadi sulit bagi mahasiswa yang tidak memiliki fasilitas internet mendukung. Mahasiswa akan dirugikan dengan biaya tambahan untuk menikmati fasilitas tersebut, rendahnya kualitas koneksi internet, dan hambatan lingkungan yang tidak mendukung proses belajar mengajar. Hal ini dapat berdampak pada menurunnya Indeks Prestasi Kumulatif atau IPK. (UNESCO \& IESALC, 2020).

Gangguan jiwa pada mahasiswa akan menyebabkan tidak optimalnya mengikuti proses belajar selama masa studi. Hal ini juga dapat berpengaruh pada tahap perkembangan mahasiswa. Perlu intervensi khusus untuk menangani gangguan jiwa yang dialami oleh mahasiswa. Depresi pada mahasiswa dapat diatasi dengan menerapkan beberapa kegiatan berikut seperti, kegiatan fisik, kegiatan keagamaan dan sosial (Bhat et al., 2020), melakukan terapi perilaku kognitif (Wang et al., 2020) mindfulness terapi secara online (Franco, 2020) dan konseling online (Sahu, 2020).

Terapi kognitif dapat memberikan informasi atau bukti untuk meningkatkan kepercayaan pada kemampuan dokter untuk mendiagnosis COVID-19. Terapi kognitif dapat mengurangi perspektif penyandang COVID-19 yang melebihlebihkan risiko tertular dan kematian akibat virus ini. Terapi perilaku dapat fokus pada latihan relaksasi untuk mengatasi kecemasan dan penjadwalan aktivitas (misalnya, olahraga dan hiburan berbasis rumah) untuk mengatasi depresi pada lingkungan rumah (Wang et al., 2020).

Latihan mindfulness online mampu untuk mengurangi stress, kecemasan dan depresi secara klinis. Intervensi mindfulness online selama empat minggu efektif digunakan mahasiswa keperawatan, 
mengurangi stress, kecemasan dan depresi. Mahasiswa keperawatan memiliki akses mudah untuk melakukan latihan intervensi mindfulness online. Mahasiswa dapat mempraktikkan mindfulness kapan saja, di mana saja, dan dalam kondisi apa pun, karena aplikasi mindfulness online dapat diunduh sebagai aplikasi pada smartphone. Mahasiswa tidak harus menghadiri latihan mindfulness online dengan tatap muka (Franco, 2020).

Karena mahasiswa lebih mudah menerima aplikasi smartphone, layanan kesehatan dapat menyediakan intervensi psikoedukasi dan psikologis berbasis online atau smartphone. Layanan konseling yang tepat harus tersedia untuk mendukung kesehatan mental dan kesejahteraan mahasiswa (Sahu, 2020). Penelitian mengungkapkan bahwa layanan konseling daring pada mahasiswa dapat meningkatkan kesehatan mental siswa. Temuan ini akan bermanfaat untuk mengatasi masalah seperti depresi, kecemasan, stres, dan koping.

\section{KESIMPULAN DAN SARAN}

Depresi yang dialami mahasiswa selama masa pandemi covid-19 berada pada beberapa tingkat berkaitan dengan akademik, finansial dan waktu yang mempengaruhi kesehatan fisik maupun mental. Mahasiswa disarankan untuk tetap menjalankan aktivitas harian meski dirumah, mengikuti layanan konseling online dan melakukan latihan rileksasi yang disediakan di kampus. Hal ini dapat meningkatkan kesehatan mental mahasiswa selama pandemi COVID-19.

\section{DAFTAR PUSTAKA}

American College Health Association. (2019) American College Health Association-National college health assessment II: Reference group executive summary spring 2019.

Diperoleh dari

https://www.acha.org/documents/ncha /NCHA-

III_Fall_2019_Reference_Group_Exe cutive_Summary.pdf

Bhat, B. A., Khan, S., Manzoor, S., Niyaz, A., Tak, H. J., Anees, S., ... Ahmad, I. (2020). A study on impact of COVID-19 lockdown on psychological health, economy and social life of people in Kashmir, 5(2), 36-46.

Bouey, J., \& Dong, L. (2020). Public mental health crisis during COVID-19 pandemic, China. Emerging Infectious Diseases, 26(7), 1616-18. Doi: 10.3201/eid2607.20040

Cao, W., Fang, Z., Hou, G., Han, M., Xu, X., Dong, J., \& Zheng, J. (2020). The psychological impact of the COVID19 epidemic on college students in China. Psychiatry Research, 287, 112934. doi: 10.1016/j.psychres.2020.112934

Franco, H. (2020). Effects of an online mindfulness program on depression, anxiety, stress, and coping among undergraduate second-year nursing students. Diperoleh dari https://scholarworks.uttyler.edu/cgi/vi ewcontent.cgi? article $=1115 \&$ context $=$ nursing_grad

Giacalone, A., Rocco, G., \& Ruberti, E. (2020). Physical health and psychosocial considerations during the COVID-19 outbreak. Psychosomatics, 1-6. doi: 10.1016/j.psym.2020.07.005

Grubic, N., Badovinac, S., \& Johri, A. M. (2020). Student mental health in the 
midst of the COVID-19 pandemic: A call for further research and immediate solutions. International Journal of Social Psychiatry, 66(5), 517-8, doi: $10.1177 / 0020764020925108$

Hamada, K., \& Fan, X. (2020). The impact of COVID-19 on individuals living with serious mental illness. Schizophrenia Research. doi: j.schres.2020.05.054

Hulukati, W., \& Djibran, M. R. (2018). Analisis tugas perkembangan mahasiswa Fakultas Ilmu Pendidikan Universitas Negeri Gorontalo. Jurnal Bikotetik, 2(1), 73-80. doi: 10.26740/bikotetik.v2n1.p73-80

Lu, H., Nie, P., \& Qian, L. (2020). Do quarantine experiences and attitudes towards COVID-19 affect the distribution of psychological outcomes in China? A quantile regression analysis. Nature Public Health Emergency Collection, 1-18. doi: 10.1007/s11482-020-09851-0

Machfoedz, I. (2009). Metodologi penelitian bidang kesehatan, keperawatan, kebidanan, kedokteran. Yogyakarta: Fitramaya.

Bouey, J., \& Dong, L. (2020). Public mental health crisis during COVID-19 pandemic, China. Emerging Infectious Diseases, 26(7), 1616-18. Doi: 10.3201/eid2607.20040

Mutyah, D., Ayu, S. C., \& Damayanti, N. (2020). Hubungan karakteristik individu (jenis kelamin dan usia) terhadap perkembangan psikososial mahasiswa keperawatan di Surabaya. Journal of Health Sciences, 13(01), 58-65. doi: 10.33086/jhs.v13i01.1317
Permana, R. H., Wardati, M. A., \& Sirodj, D. A. N. (2017). Gambaran krisis psikologis mahasiswa tingkat pertama program sarjana Universitas Islam Bandung. Journal of Psychological Research, 92-103.

Sahu, P. (2020). Closure of universities due to Coronavirus Disease 2019 (COVID-19): Impact on education and mental health of students and academic ataff. Cureus, 12(4), 1-6. Doi: 10.7759/cureus.7541

Sarokhani, D., Delpisheh, A., Veisani, Y., Sarokhani, M. T., Manesh, R. E., \& Sayehmiri, K. (2013). Prevalence of depression among university students: A systematic review and metaanalysis study. Depression Research and Treatment, 1-6. doi: $10.1155 / 2013 / 373857$

Thomas, E. (2020). Coronavirus: Impact on young people with mental health needs. YoungMinds. Diperoleh dari https://youngminds.org.uk/media/370 8/coronavirus-. 